\title{
Phytoplankton community structure and species assemblage succession in a shallow tropical lake (Lake Guiers, Senegal)
}

\author{
Marc Bouvy ${ }^{1,2, *}$, Ngansoumana Ba ${ }^{1}$, Samba Ka $^{1}{ }^{,}$, Seyni Sane ${ }^{1}$, Marc Pagano $^{1}$, \\ Robert Arfi ${ }^{1}$
}

${ }^{1}$ Centre Institut de Recherche pour le Développement (IRD), Bel Air, UR 167 Cyroco, BP 1386, Dakar, Senegal

${ }^{2}$ Present address: University Montpellier II, IRD UR 167 Cyroco, Equipe EMMA, Laboratoire Ecosystèmes Lagunaires, Place Eugène Bataillon, Case 093, 34095 Montpellier Cedex, France

\begin{abstract}
Phytoplankton species composition and seasonal changes were investigated monthly in Lake Guiers, one of the largest lakes in West Africa. Taxonomic composition, diversity, biovolume and abundance of phytoplankton were studied at 3 representative stations from March 2002 to March 2003, in relation to various climatic factors (wind, insolation), physical and chemical factors (temperature, conductivity, nutrients) and biological factors (zooplankton grazing). A total of 111 species of phytoplankton belonging to 7 algal classes were identified, predominately Chlorophyceae (32\% of species) followed by Cyanobacteria (25\%) and Bacillariophyceae (diatoms, 15\%). From December to March, a period characterised by low temperature, solar insolation and north-easterly winds that mixed the water column, the community was dominated by the diatom Fragilaria sp. and cyanobacterium Anabeana miniata. From April to September, during higher temperatures, solar insolation and predominant north-westerly winds that mixed the water column less effectively, the community was dominated by cyanobacteria Cylindrospermopsis raciborskii and Lyngbya versicolor. A statistical approach based on co-inertia analysis was used to describe the phytoplankton/ environment relationships, in particular the factors governing the presence of C. raciborskii. The phytoplankton community was characterised by a clear succession of species groups: Fragilaria sp.-A. miniata (November to March) $\rightarrow$ Microcystis aeruginosa (March to May) $\rightarrow$ C. raciborskiiL. versicolor (June to November). Finally, a functional approach originally designed for temperate zones was applied to the algal groups (11 functional groups), which gave valuable information on algal strategies in a shallow tropical lake.
\end{abstract}

KEY WORDS: Phytoplankton · Cylindrospermopsis $\cdot$ Fragilaria · Functional group · West Africa

\section{INTRODUCTION}

Natural (lakes) and artificial (reservoirs) bodies of water in the tropics are ecosystems in which environmental characteristics and biological features are strongly influenced by extra flow when rivers flood intermittently with periodic drying out (Thornton et al. 1990). During their annual development, phytoplankton communities pass through several distinct successions, with predominant species, abundant species and rare species coexisting (Salmaso 2003). Most phytoplankton species are competitors for the same limited resources of their environment, principally light and nutrients. According to Sommer (1989), the annual variation of predominant species can be predicted, even though the taxa that dominate communities will depend upon complex factors such as retention time, nutrient load and grazing pressure. However, it is clear that there are many ecological processes, such as competition and/or commensalism for a nutrient or the 
pressure exerted by one or many predators, acting simultaneously within a community in a particular habitat or space. Cyanobacteria are more abundant than other classes of algae in most shallow tropical lakes, and are often competitors under conditions of high turbidity (Padisák 1997).

Algal successions in tropical aquatic systems are generally characterised by a sharp contrast between the 2 main seasons (dry/wet-flood season): cyanobacteria/diatoms in Lake Victoria (Lung'ayia et al. 2000), cyanobacteria/chlorophytes-chroococcales in Lake Tanganyika (Descy et al. 2005) and cyanobacteria/ diatoms-chlorophytes-chroococcales in many reservoirs in north-east Brazil (Bouvy et al. 2000, 2003). According to Salmaso (2003), temporal changes in phytoplankton composition can represent a complex environmental gradient driving annual succession; thus, environmental variables may act jointly as a complex forcing factor that selects seasonal groups of species sharing similar requirements. In a given environment and for each season, the species association linked to an ecotype can be formed by a consortium of different genotypes with different biochemical and/or physiological properties (Kruk et al. 2002, Reynolds et al. 2002). Reynolds et al. (2002) and Huszar et al. (2003) considered that a functional approach, based on morphological-ecological properties, can be used as a quantitative method to describe community structure and changes. This concept appears to be a useful and appropriate tool that can improve our understanding of the impact of major environmental engineering works aiming to mitigate the effects of eutrophication on the phytoplankton community of an aquatic system subjected to anthropogenic pressure, such as in Lake Rodó, Uruguay (Kruk et al. 2002).

In Senegal, Lake Guiers, one of the largest in West Africa, is fed by the Senegal River and is an important source of drinking water for several cities, Dakar in particular. Several multidisciplinary studies of Lake Guiers and its surrounding areas have shown the lake to be subject to growing eutrophication, especially in the central zone where the pumping station ( $\mathrm{N}^{\prime}$ Gnith) is located (Cogels et al. 2001, Varis \& Fraboulet-Jussila 2002, Berger et al. 2006). Irrigated sugar cane plantations in the north zone of the lake, with various micro pollutant inputs and waste water discharge, have a fundamental impact on its ecosystem (Cogels et al. 2001), and hydrodynamic management of the Senegal river (based on 2 dams constructed between 1985 and 1987) has made it possible to stabilise the water level in the lake and avoid seawater incursions (Cogels et al. 2001). One direct consequence of the various environmental engineering works and increasing level of eutrophication has been a shift in the phytoplankton community, especially in the cyanobacteria, from which 8 potentially toxic species including Cylindrospermopsis raciborskii have been identified (Cogels et al. 2001). The presence of C. raciborskii in a drinking water reservoir is worrying for many reasons, e.g. its invasive character (Padisák 1997, Bouvy et al. 2000), its potential toxicity with a wide range of toxins (Humpage et al. 1994), and the significant changes that it can induce in the structure of other plankton components (Bouvy et al. 2001, Leonard \& Paerl 2005).

In order to demonstrate the influence of environmental factors on the composition and succession of phytoplankton species on Lake Guiers, a survey using monthly sampling from March 2002 to March 2003 was conducted at 3 representative stations in the central zone of the lake. The objectives of this study were to (1) describe the phytoplankton community (composition, diversity, biovolume, abundance), (2) identify the succession of species assemblages using a statistical correlation between their occurrence and the changing environment, and (3) apply the functional scheme outlined by Reynolds et al. (2002) designed for temperate zones to the algal strategies observed in tropical Lake Guiers.

\section{MATERIALS AND METHODS}

Study area. Lake Guiers is the largest lake in Senegal $\left(15^{\circ} 10^{\prime} \mathrm{N}, 16^{\circ} 08^{\prime} \mathrm{W}\right)$, with a mean surface area of $300 \mathrm{~km}^{2}$ and a volume of $600 \times 10^{6} \mathrm{~m}^{3}$. The region is characterised by a sahelian climate with a short rainy season from July to September with irregular precipitation. Annual rainfall is generally between 200 and $250 \mathrm{~mm}$. A dam was built in 1985 at Diama, $27 \mathrm{~km}$ upstream of Saint Louis, to stop seawater flowing up the Senegal River (Fig. 1). A second dam was built in 1987 for hydroelectric power, $1000 \mathrm{~km}$ upstream on the Bafing River at Manantali, Mali. This dam controls part of the Senegal River flow (Albergel et al. 1993). Two hydrological periods can now be distinguished: (1) a filling period between August and October with inflow from the Senegal River into the lake, and (2) a stable period of 9 mo with little interaction between the river and the lake (Cogels \& Gac 1993).

Sampling and analyses. Samples were collected monthly from March 2002 to March 2003 at 3 representative stations in the central zone, near N'Gnith village, where the pumping station for the drinkingwater facility is located (Fig. 1). Stn 1 was located in the central channel of the lake (close to $3 \mathrm{~m}$ depth), Stn 2 in an embayment (close to $2 \mathrm{~m}$ depth), and Stn 3 inside the dense aquatic vegetation of rooted semisubmerged macrophytes, mainly the southern cattail Typhae domingensis (close to $1 \mathrm{~m}$ depth). Wind direction and speed were recorded hourly using a Davis 


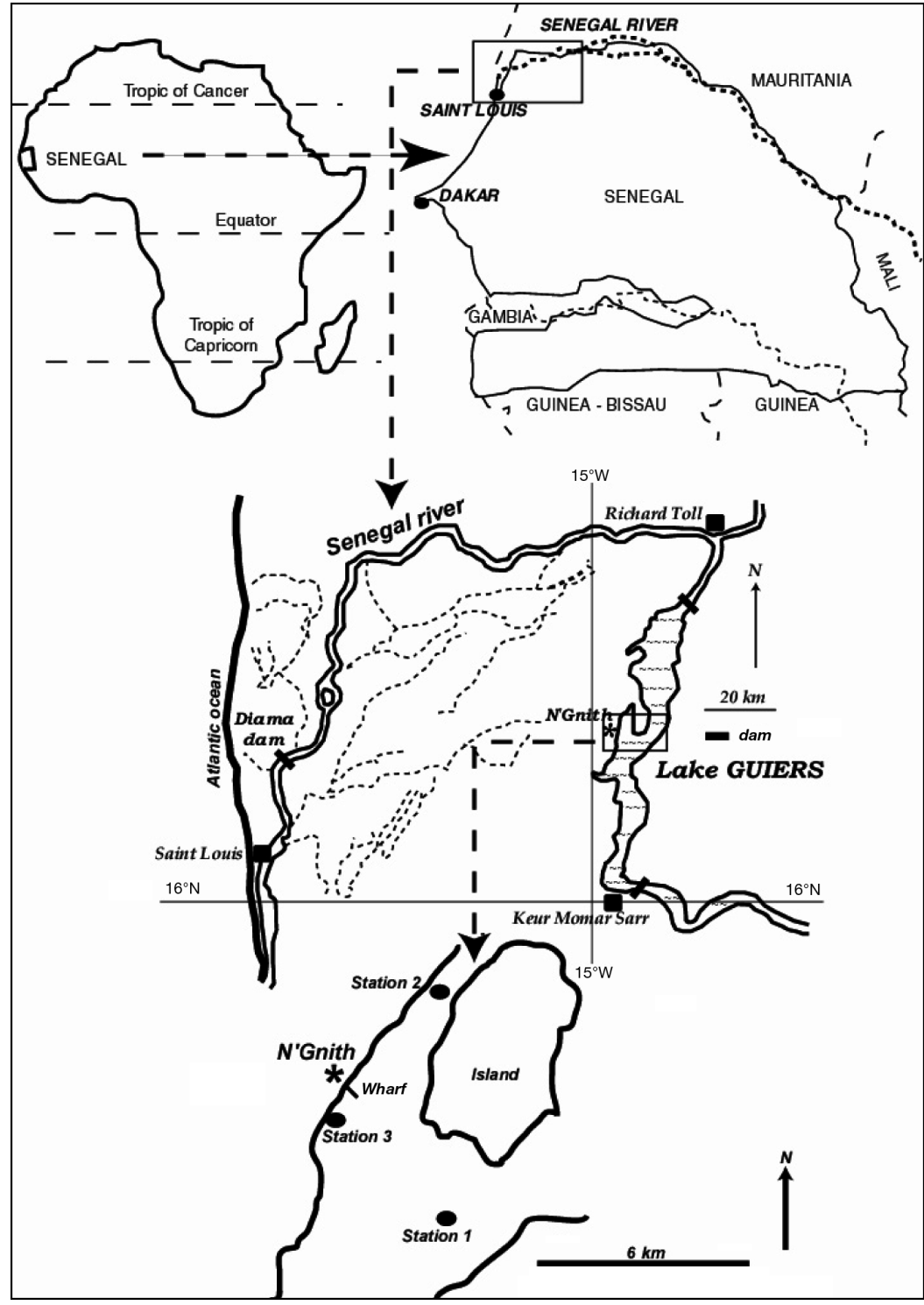

Fig. 1. Location of Lake Guiers, Senegal; the 3 stations are located in front of $\mathrm{N}^{\prime}$ Gnith village in the central zone of the lake profiles using a Li-Cor 193 spherical quantum sensor. Vertical profiles of temperature, in vivo fluorescence, conductivity and dissolved oxygen were recorded using a Sea Bird CTD recorder (SBE 19). $\mathrm{pH}$ was measured with a WTM 320/SET pH-meter. Samples for dissolved inorganic nutrient determination $\left(\mathrm{NO}_{3}-\mathrm{N}, \mathrm{NH}_{4}-\mathrm{N}, \mathrm{PO}_{4}-\mathrm{P}\right)$ were filtered using Whatman GF/F fibreglass filters, stored at $-20^{\circ} \mathrm{C}$ and analysed using the method of Strickland \& Parsons (1972). Alkalinity was measured by titration (Gran 1952). Turbidity was estimated by seston weights determined after filtration through preweighed Whatman GF/F filters, dried at $105^{\circ} \mathrm{C}$ for $48 \mathrm{~h}$ and reweighed. Zooplankton were sampled with cylindro-conical nets $(30 \mathrm{~cm}$ diameter aperture, $80 \mathrm{~cm}$ height, $60 \mu \mathrm{m}$ mesh size). The net was laid on the bottom and hauled in 1 min later. Samples were preserved in buffered formaldehyde at $5 \%$ concentration. Organisms were counted in the whole sample or in v/v sub-samples taken using wide bore piston pipettes ( 0.5 to $5 \mathrm{ml}$ ) and including at least 300 individuals.

Water samples for chl $a$ analysis were filtered through Whatman GF/F filters and stored in liquid nitrogen. $\mathrm{Chl} a$ concentrations were determined by methanol extraction and fluorometry (Yentsch \& Menzel 1963). For phytoplankton counts, $50 \mathrm{ml}$ of water was placed in a polyethylene bottle and fixed immediately with Lugol's iodine solution. Organisms were identified using an inverted microscope and weather station installed on the N'Gnith wharf. Total irradiation was measured hourly using a Li-Cor 200SB pyranometer. A total of 13 collections based on 2 depths were performed during the annual cycle. Sampling was conducted around noon using a PVC tube ( $3.5 \mathrm{~cm}$ diameter, $2 \mathrm{~m}$ length) with 2 separate compartments immersed vertically to obtain an integrated sample of the water column: at 0 to $1.5 \mathrm{~m}$ and 1.5 to $2 \mathrm{~m}$ for the deeper Stns 1 and 2, and at 0 to $0.5 \mathrm{~m}$ and 0.5 to $1 \mathrm{~m}$ for the shallower Stn 3. Water from each compartment ('surface' and 'bottom') was then stored in $1.5 \mathrm{l}$ polycarbonate bottles. Water transparency was assessed using a $30 \mathrm{~cm}$ Secchi disk. The euphotic depth was estimated from values obtained on vertical counted following the Utermöhl (1958) method (5 to $10 \mathrm{ml}$ sedimented volume, $48 \mathrm{~h}$ sedimentation time) in random fields. For dominant taxa, at least 400 cells were counted. Phytoplankton species were identified using tables published by Lauterborn (1915), Skuja (1956), Grönblad et al. (1958), Couté \& Rousselin (1975), Komárek \& Anagnostidis (1989) and Compere (1991). Cell volume was estimated for each species using the measured dimensions and geometric forms that closely matched cell morphology (Smayda 1978, Sun \& Liu 2003); biovolume was expressed in $\mathrm{mm}^{3} \mathrm{l}^{-1}$. Species richness was expressed as the number of taxa per sample. Diversity was estimated using the Shannon-Wiener diversity index (Shannon \& Weaver 1963) based on abundance data. 
Data processing. Relationships between environmental and biological variables were studied using multivariate analysis. Principal component analysis (centred PCA) was performed for each of the 2 data sets: an environmental table based on 17 variables, and a biological table based on 19 variables. Results of these PCAs were associated using co-inertia analysis (CIA), which can be used to process 2 tables with different numbers of factors (Dolédec \& Chessel 1994). Two sets of factor scores are obtained for the sampling points: scores of the rows 'seen by the environmental variables' and scores of the rows 'seen by the biological variables'. The significance of the CIA was tested after randomisation of the results by a repeated random permutation of the rows of both tables and comparison with results obtained by PCA. The resulting distribution of 2000 replicated matches of 2 arrays gave an estimated significance of $p<0.001$. Data processing was performed using ADE-4 software (Thioulouse et al. 1997).

Statistical analyses. Differences among results for phytoplankton and zooplankton species at different sampling dates and stations were tested using ANOVA, followed by a Bonferroni test when the differences were significant. All data were transformed $[x \rightarrow$ $\log (x+1)]$. Differences were considered as significant when $\mathrm{p}<0.05$.

\section{RESULTS}

\section{Environmental conditions}

North winds predominated during the survey ( $84 \%$ of occurrence), blowing from north-northwest (NNW

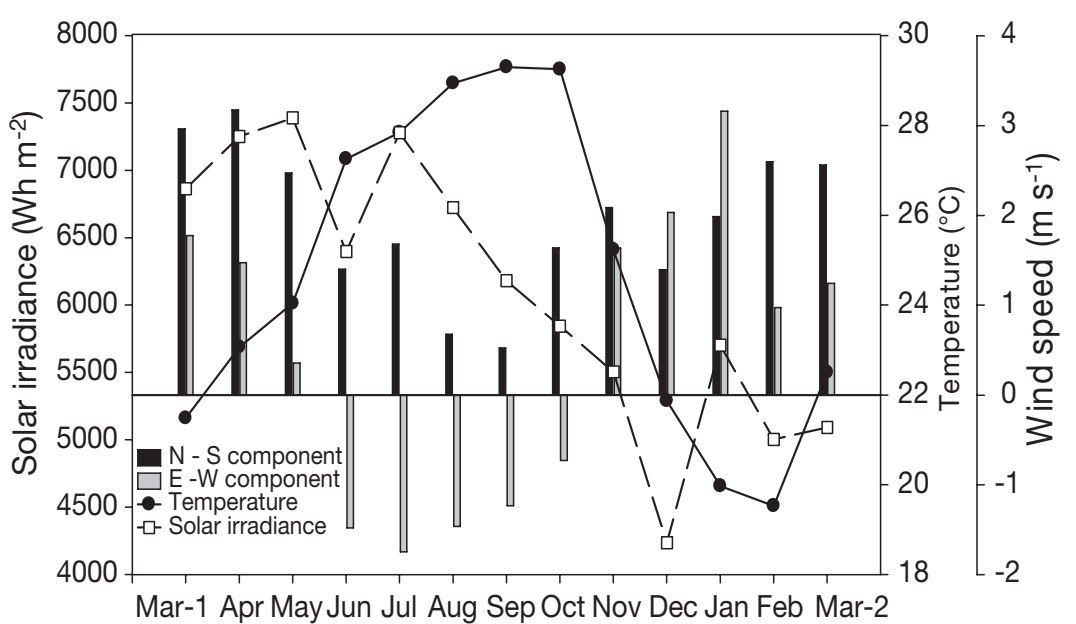

Fig. 2. Variations in wind speed, solar irradiance and water temperature in Lake Guiers from March 2002 to March 2003. Values of wind speed are positive for N and $\mathrm{E}$ components, and negative for $\mathrm{S}$ and $\mathrm{W}$ components maritime trade winds, $25 \%$ from May to November) and from north-northeast (NNE continental trade winds, 66\% from December to February) (Fig. 2). Average wind speed was $3.4 \mathrm{~m} \mathrm{~s}^{-1}$, with high wind speeds (up to $7.3 \mathrm{~m} \mathrm{~s}^{-1}$ ) recorded from January to April. Low wind speeds (down to $1.2 \mathrm{~m} \mathrm{~s}^{-1}$ ) were recorded in November and December. The water temperature was high throughout the survey, with an average value of $26.2^{\circ} \mathrm{C}$ at $0.5 \mathrm{~m}$ (Fig. 2). The temperature was slightly lower near the bottom $\left(0.4^{\circ} \mathrm{C}\right.$ lower on average), suggesting thermal homogenization of the water column. The seasonal cycle was marked, with high temperatures recorded between June and October (mean $29.5^{\circ} \mathrm{C}$ ) and low temperature recorded from November to February. Total daily irradiation varied between $4235 \mathrm{Wh} \mathrm{m}^{-2}$ in December and $7388 \mathrm{Wh} \mathrm{m}^{-2}$ in July (Fig. 2). Conductivity varied between 164 and $204 \mu \mathrm{S}$ $\mathrm{cm}^{-1}$ (mean $181 \mu \mathrm{S} \mathrm{cm}^{-1}$ ) and values did not differ significantly among the 3 stations throughout the survey $\left(\right.$ ANOVA $\left._{i} \mathrm{p}=0.946\right)$. Mean $\mathrm{pH}$ was 7.9 at Stns 1 and 2, whereas lower values were recorded (mean 7.2) at Stn 3 inside the Typhae domingensis stand. Alkalinity values were low (ranging between 0.99 and $1.03 \mathrm{mEq} \mathrm{I}^{-1}$ ). $\mathrm{pH}$ and alkalinity showed the same seasonal pattern, with highest values recorded in October-November.

Sub-surface water was slightly under-saturated in dissolved oxygen (close to 90\%) at Stns 1 and 2, with very similar values recorded near the bottom. However, at Stn 3 inside the Typhae domingensis zone, a marked difference was observed down the water column with much lower dissolved oxygen values near the bottom (close to $20 \%$ saturation in January 2003), but no anoxic conditions were observed during the survey. Mean Secchi depths ranged between 68 and $70 \mathrm{~cm}$ and high values were recorded in July $(94 \mathrm{~cm}$ at Stn 1). Euphotic depth was between 2 and $3 \mathrm{~m}$ (mean $2.3 \mathrm{~m}$ ), and therefore the whole water column was favourable for the growth of algae. No statistically significant difference in water transparency was observed among the 3 stations (ANOVA; $p=0.966$ ). Seston weights revealed a marked seasonal cycle, associated with wind-induced particle resuspension. Low values were recorded at all stations from June to September; in contrast, from January to March when NNE winds prevailed, high values were recorded at Stn 1 and low values were recorded at Stn 3 (the latter was sheltered from the wind by macrophytes). Ammonium was the major form of dissolved inorganic nitrogen (DIN), with low mean concentrations of $9.8,7.4$ and $6.3 \mu \mathrm{g}$ 
$\mathrm{NH}_{4}-\mathrm{N} \mathrm{l}^{-1}$ at Stns 1, 2 and 3, respectively. Mean DIN concentrations varied between 7 and $14 \mathrm{\mu g} \mathrm{l}^{-1}$, with 2 peaks in June (between 42 and $56 \mathrm{\mu g} \mathrm{l}^{-1}$ ) and September (between 14 and $28 \mu \mathrm{g} \mathrm{l}^{-1}$ ). Mean orthophosphate (SRP) concentrations ranged between $3.8 \mu \mathrm{g}$ $\mathrm{PO}_{4}-\mathrm{P} \mathrm{l}^{-1}$ at Stn 2 and 6.1 $\mathrm{PO}_{4}-\mathrm{P} \mathrm{l}^{-1}$ at Stn 1, with low values recorded between April and June, coinciding with NNW winds that are less favourable to sediment resuspension. For both $\mathrm{N}$ and $\mathrm{P}$, no significant difference in concentration was observed between the 2 depths sampled throughout the survey (ANOVA; $\mathrm{p}>0.5$ ).

\section{Phytoplankton community}

There was no statistically significant differences in phytoplankton abundance among stations (ANOVA; $\mathrm{p}=0.903)$ or sampled depths $\left(\right.$ ANOVA $\left._{i} \mathrm{p}=0.899\right)$. Fig. 3 shows variations in mean algal abundance for all stations and depths studied $(\mathrm{n}=6)$. An obvious pattern of phytoplankton abundance was recorded, with val-

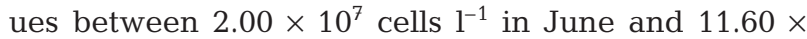
$10^{7}$ cells l$^{-1}$ in October (Fig. 3) to give a mean of $5.19 \times$ $10^{7}$ cells l$^{-1}$ (coefficient of variation $\mathrm{CV}=40 \%$ ). Total abundance varied significantly throughout the year (ANOVA, Bonferroni; $\mathrm{p}=0.002$ ), with significant lower values observed between April and June. There was no statistically significant difference in phytoplankton biovolume among stations (ANOVA $; \mathrm{p}=0.342$ ) or sampled depths (ANOVA; $p=0.132$ ). Contrary to abundance, biovolume did not vary significantly throughout the annual cycle (ANOVA $; \mathrm{p}=0.558)$. Total biovolume ranged from $11.3 \mathrm{~mm}^{3} \mathrm{l}^{-1}$ in July to $98.3 \mathrm{~mm}^{3} \mathrm{l}^{-1}$ in March with a mean of $31.5 \mathrm{~mm}^{3} \mathrm{l}^{-1}(\mathrm{CV}=33 \%)$ (Fig. 3). The SD of total biovolume was high from November 2002 to March 2003 owing to high values recorded at Stn 1 at the lower depth. The high level of algal resuspension associated with the wind speed and direction during this period, and location of this station in the central channel of the lake, may account for this discrepancy.

A total of 111 species of phytoplankton belonging to 7 algal classes were identified during the survey. The Chlorophyceae were the most diverse with $32 \%$ of total species, followed by the Cyanobacteria $(25 \%)$, the Bacillariophyceae $(15 \%)$ and the Zygnematophyceae $(15 \%)$. The Euglenophyceae and Xanthophyceae represented 8 and $4 \%$ of total species, respectively. The Dinophyceae was the least diversified class with $1 \%$ of total species. The classes represented 17 families and 49 genera. Most of the abundance was represented by only 3 of the 7 classes: the Bacillariophyceae, the Cyanobacteria and the Chlorophyceae. No significant differences in abundance per

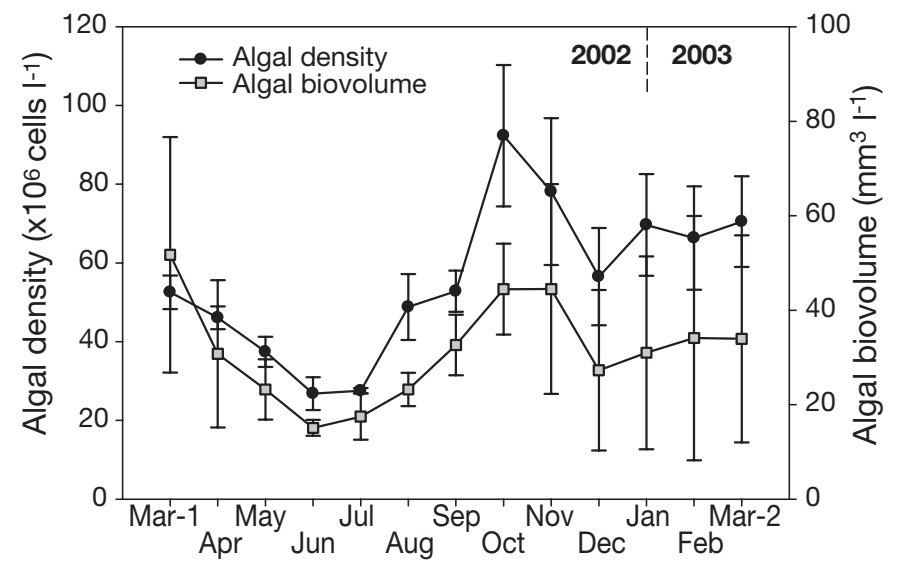

Fig. 3. Variations in algal density and biovolume in Lake Guiers from March 2002 to March 2003. Means \pm SD (n = 6) obtained from 3 stations at 2 sample depths

class were recorded either among stations or between sample depths (ANOVA; $\mathrm{p}=1$ ). Although the Chlorophyceae was the largest class in terms of number of species, this class represented only 7 to $8 \%$ of total abundance at the 3 stations over the survey. The Bacillariophyceae and Cyanobacteria constituted the bulk of phytoplankton abundance. At Stn 1, there were slightly more Bacillariophyceae than Cyanobacteria ( 47 and $41 \%$ of total abundance, respectively), whereas the opposite was noted at Stn 2 (43 and $46 \%$ respectively). At $\operatorname{Stn} 3$, these 2 classes were in equal proportions $(45 \%)$.

Among the 111 species identified, only 17 represented more than $1 \%$ of total abundance (Table 1). Of these species, 3 were prominent throughout the survey: the diatom Fragilaria sp., which was detected in $85 \%$ of samples and contributed a maximum of $74 \%$ to total phytoplankton abundance, and 2 cyanobacteria (Cylindrospermopsis raciborskii and Lyngbya versicolor), which were detected in all samples and contributed a maximum of $64 \%$ to total phytoplankton abundance. No significant differences in their abundance and biovolume were observed among stations or between sampled depths (ANOVA; $p>0.400$ ). However, each species exhibited a marked annual cycle in terms of abundance and biovolume (ANOVA, Bonferroni; $\mathrm{p}=0.001)$. C. raciborskii showed the highest values between July and October (maximum abundance of $1.75 \times 10^{7}$ trichomes $\mathrm{l}^{-1}$ and maximum biovolume of $8.41 \mathrm{~mm}^{3} \mathrm{l}^{-1}$ ), and low values between December and March (Fig. 4). L. versicolor exhibited the same annual patterns of abundance and biovolume as recorded for C. raciborskii. Means, however, were lower, with maximum abundance of $9.91 \times 10^{6}$ trichomes $\mathrm{l}^{-1}$ and maximum biovolume of $3.58 \mathrm{~mm}^{3} \mathrm{l}^{-1}$ (Fig. 4). Fragilaria sp. showed a marked cycle, with high values 
Table 1. Dominant phytoplankton species (contribution $>5 \%$ to total abundance) in Lake Guiers at each station for 2 sampled depths (S: $0.5 \mathrm{~m}$ depth, B: $0.5 \mathrm{~m}$ from bottom) from March 2002 to March 2003; black boxes: species absence

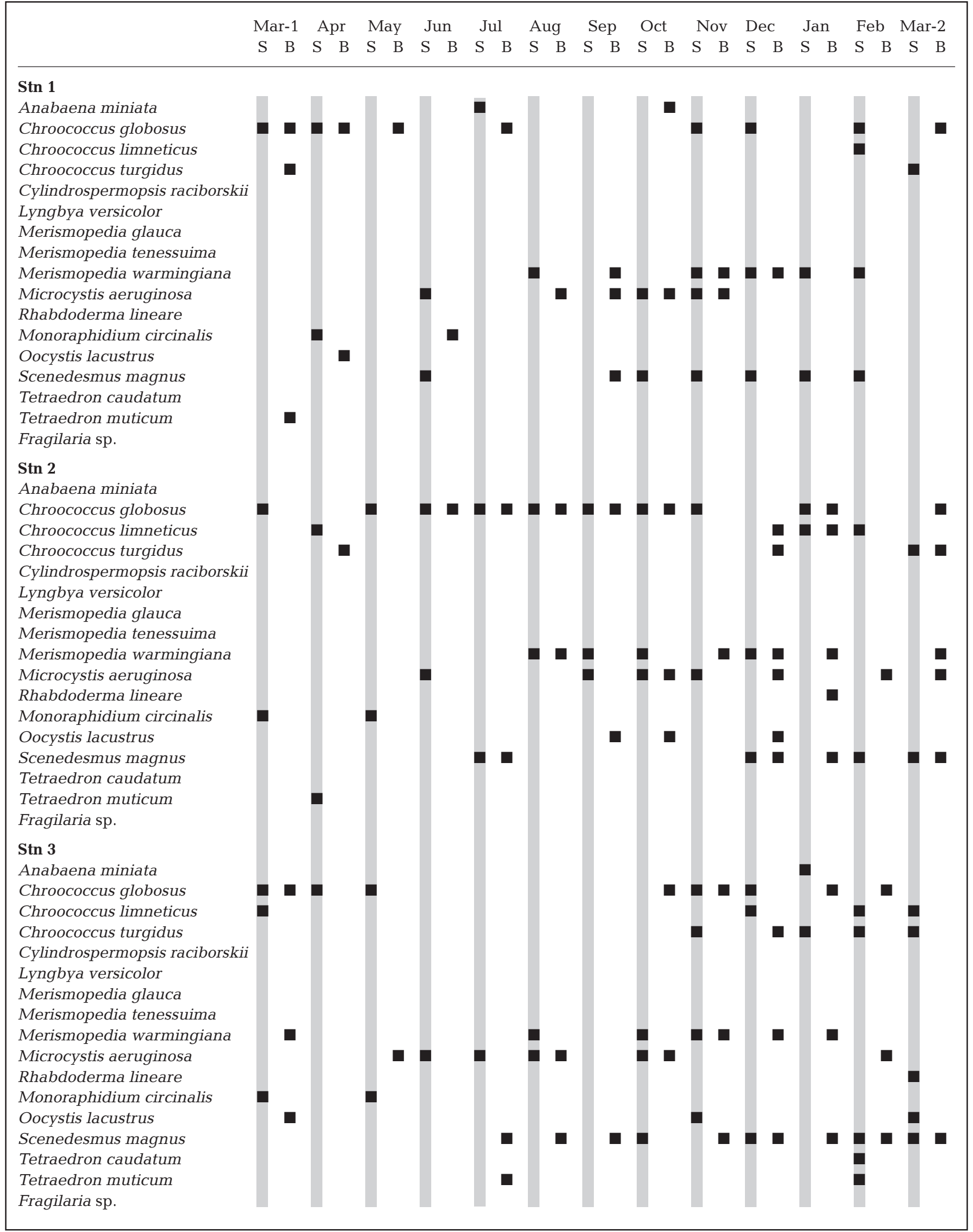




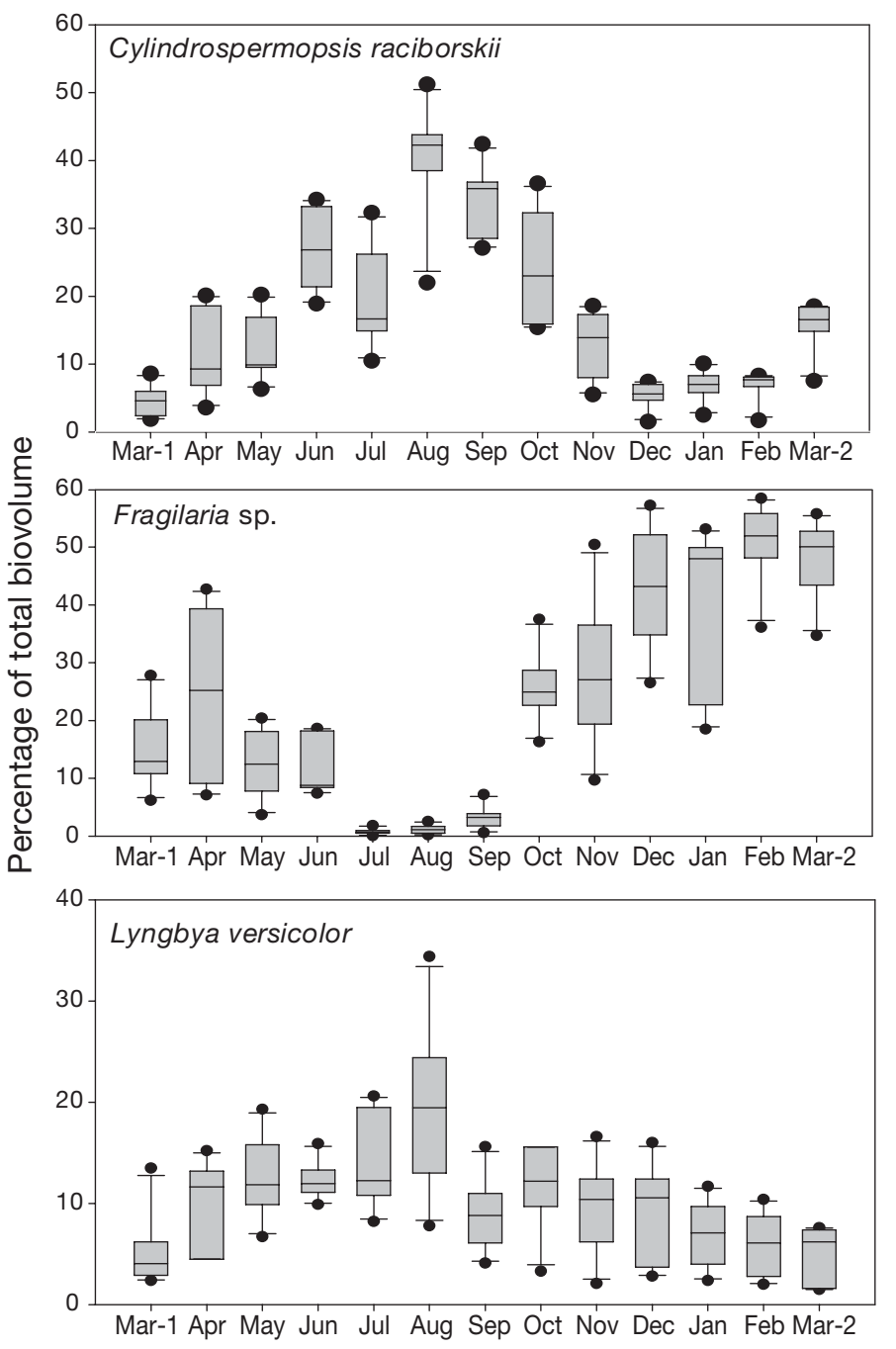

Fig. 4. Variations in percentages of 3 dominant species in Lake Guiers from March 2002 to March 2003. Data obtained from 3 stations and 2 sampled depths. Whiskers (error bars indicate the 90th and 10th percentiles. The line within the box marks the median. Black dots indicate the 5th and 95th percentiles

recorded between October and March (abundance: $3.86 \times 10^{7}$ cells $\mathrm{l}^{-1}$; biovolume: $10.54 \mathrm{~mm}^{3} \mathrm{l}^{-1}$ ). From April to September, the abundance and biovolume were lower, with a remarkable absence of this diatom observed in July-August at Stn 2 (Fig. 4).

Some of the 'secondary species' exhibited high frequencies (between 54 and $92 \%$ ) at least once in various samples to represent more than $5 \%$ of total abundance: the cyanobacteria Anabaena miniata, Chroococcus globosus, C. limneticus, C. turgidus, Merismopedia glauca, M. tenessuima, M. warmingiana, Microcystis aeruginosa and Rhabdoderma lineare, and the Chlorophyceae Monoraphidium circinalis, Oocystis lacustrus, Scenedesmus magnus,

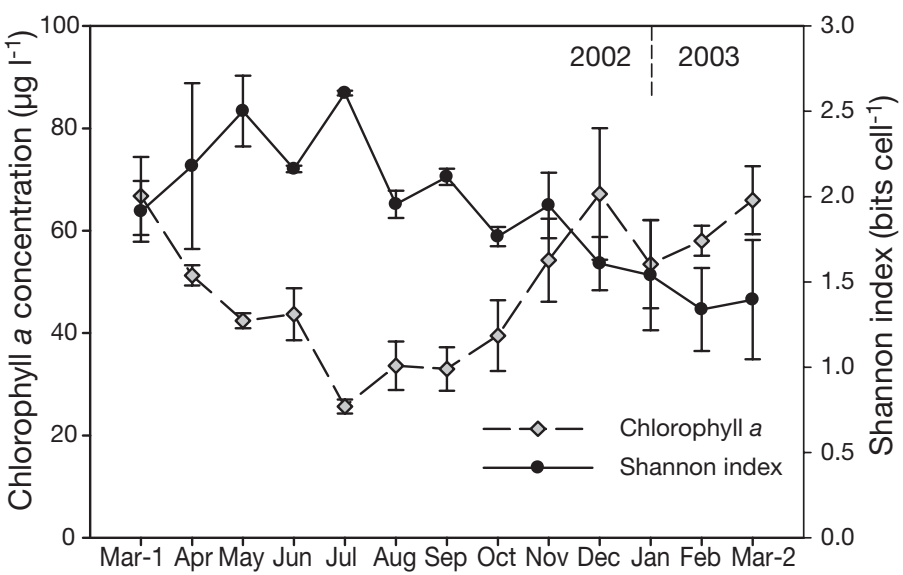

Fig. 5. Variations in chl a concentration and ShannonWiener's diversity index in Lake Guiers from March 2002 to March 2003. Means \pm SD $(n=6)$ obtained from 3 stations at 2 sampled depths

Tetraedron caudatum and T. muticum. No significant differences were observed in terms of abundance and biovolume among stations or between sample depths for these species. However, most species exhibited a marked seasonal cycle, except $M$. glauca and $R$. lineare (Table 1).

Significant differences in Shannon-Wiener's diversity index were recorded between depths (ANOVA, Bonferroni; $\mathrm{p}=0.045$ ) but not among stations (ANOVA; $\mathrm{p}=0.884$ ). The diversity index showed a marked cycle, with high values observed between April and September (2.03 to 2.11 bits cell ${ }^{-1}$ ) when Cylindrospermopsis raciborskii and Lyngbya versicolor were predominant (Fig. 5). Chl a concentrations ranged between 25.9 and $69.9 \mu \mathrm{g} \mathrm{l}^{-1}$, with a seasonal pattern close to that observed for total algal abundance and biovolume, except that the highest value $\left(70 \mu \mathrm{g} \mathrm{l}^{-1}\right.$; Fig. 5) was recorded in March 2003.

\section{Co-inertia analysis (CIA)}

The 2 PCAs on environmental and biological variables were performed on the whole data set (13 sampling dates, 17 environmental parameters, 18 biological variables; Table 2). The first 2 eigenvalues of the CIA accounted for more than $80 \%$ of total variability (89.8\% for Stn 1, 86.8\% for Stn 2, and 80.7\% for Stn 3). Therefore, the analysis concentrated on the 2 first components. The values of the variances of environmental and biological tables projected onto the axes (F1, F2) of the CIA were close to the values of variables of these tables projected onto the same axes of the PCA. For example, for Stn 1, the factorial plane of the CIA for the biological table accounted for $54.3 \%$ of variance, 
Table 2. Co-inertia analysis (CIA). (a) Environmental parameters and (b) biological variables studied during the annual cycle in Lake Guiers. Environmental and biological systems for CIA are defined from these parameters and variables

\begin{tabular}{|c|c|c|}
\hline & Units & Comments \\
\hline \multicolumn{3}{|c|}{ (a) Environmental parameters } \\
\hline Depth & $\mathrm{m}$ & \\
\hline Alkalinity & $\mathrm{mEq} \mathrm{l}^{-1}$ & \\
\hline Conductivity & $\mu \mathrm{S} \mathrm{cm} \mathrm{cm}^{-1}$ & \\
\hline Turbidity & $\mathrm{mg} \mathrm{l}^{-1}$ & Seston weight \\
\hline $\begin{array}{l}\text { Dissolved oxygen } \\
\text { pH }\end{array}$ & $\mathrm{mg} \mathrm{l}^{-1}$ & \\
\hline Surface temperature & ${ }^{\circ} \mathrm{C}$ & \\
\hline Irradiance & Wh m ${ }^{-2}$ & Daily solar irradiance \\
\hline Euphotic zone & $\mathrm{m}$ & \\
\hline Secchi depth & $\mathrm{cm}$ & \\
\hline \multicolumn{3}{|l|}{ In vivo fluorescence } \\
\hline North wind & $\mathrm{m} \mathrm{s}^{-1}$ & North direction \\
\hline Chl a & $\mu \mathrm{g} \mathrm{l}^{-1}$ & \\
\hline $\mathrm{N}-\mathrm{NO}_{3}$ & $\mu g 1^{-1}$ & Dissolved nitrate \\
\hline $\mathrm{N}-\mathrm{NH}_{4}$ & $\mu g 1^{-1}$ & Dissolved ammonia \\
\hline $\mathrm{P}-\mathrm{PO}_{4}$ & $\mu g \mathrm{l}^{-1}$ & Dissolved phosphorus \\
\hline \multicolumn{3}{|l|}{ (b) Biological variables } \\
\hline Algal density & cells $1^{-1}$ & \\
\hline Algal biovolume & $\mathrm{mm}^{3} \mathrm{l}^{-1}$ & \\
\hline Richness & & Species number \\
\hline Shannon-Wiener index & bits cell ${ }^{-1}$ & \\
\hline Rotifers & ind. $\mathrm{l}^{-1}$ & Abundance \\
\hline Copepods & ind. $1^{-1}$ & Abundance \\
\hline Cladocerans & ind. $1^{-1}$ & Abundance \\
\hline Cyl & ind. $\mathrm{l}^{-1}$ & Cylindrospermopsis raciborskii \\
\hline Lyn & ind. $\mathrm{l}^{-1}$ & Lyngbya versicolor \\
\hline Mic & ind. $1^{-1}$ & Microcystis aeruginosa \\
\hline Mer & ind. $\mathrm{l}^{-1}$ & Merismopedia (3 species) \\
\hline Ana & ind. $\mathrm{l}^{-1}$ & Anabaena miniata \\
\hline Chr & ind. $\mathrm{l}^{-1}$ & Chroococcus (3 species) \\
\hline Fra & ind. $\mathrm{l}^{-1}$ & Fragilaria sp. \\
\hline Tet & ind. $1^{-1}$ & Tetraedron (2 species) \\
\hline $\mathrm{OoC}$ & ind. $\mathrm{l}^{-1}$ & Oocystis lacustrus \\
\hline Rha & ind. $1^{-1}$ & Rhabdoderma lineare \\
\hline Sce & ind. $\mathrm{l}^{-1}$ & Scenedesmus magnus \\
\hline
\end{tabular}

association between station depth, in vivo fluorescence and chl a.

In the biological system (Fig. 6B), the first axis (F1) showed a strong opposition between the diatom Fragilaria sp. (Fra) (associated with total phytoplankton abundance and biomass) and the 2 prominent cyanobacteria Cylindrospermopsis raciborskii (Cyl) and Lyngbya versicolor (Lyn). These relationships were less marked at Stn 3. Moreover, Fragilaria sp. was also in opposition to species richness and ShannonWiener's diversity index, especially at Stns 2 and 3. Fragilaria sp. was always associated with the non-predominant cyanobacterium Anabaena miniata (Ana). The cyanobacterium Microcystis aeruginosa (Mic) was isolated in the factorial plane, generally opposed to alkalinity and $\mathrm{pH}$. Some secondary species represented by the chlorophyceae Monoraphidium circinalis (Mon; data not shown) and 2 species of Tetraedron (Tet) showed strong associations in the environment system with $C$. raciborskii. On the contrary, the 3 colonial species of the cyanobacteria genus Chroococcus (Chr) showed no relationships with other algal species. The 3 major groups of zooplankton (rotifers, copepods, cladocerans) were strongly associated with each other, and were linked with the prominent cyanobacteria $C$. raciborskii and L. versicolor while being in opposition to Fragilaria sp. These associations were less strong at Stn 3.

Finally, the centroid positions of each sample at the 3 stations exhibited a remarkable seasonal pattern over the

and the factorial plane for the environmental table accounted for $61.1 \%$ of variance. Hence, the CIA was able to demonstrate a co-structure between the 2 data sets.

In the environmental system for Stns 1 and 2 (open water), the first axis (F1) showed an association between temperature, irradiance, conductivity, euphotic depth and Secchi depth, which were opposed to NE wind, chl a, turbidity and dissolved oxygen (Fig. 6A). The second axis (F2) was less informative, showing an opposition between alkalinity and depth. It is important to note the low contribution of dissolved nutrients in the factorial plane. For Stn 3, located inside the macrophyte stand, turbidity was not a significant variable, whereas dissolved nutrients (ammonium and phosphate) were opposed to dissolved oxygen, alkalinity and $\mathrm{pH}$ (Fig. 6A). The second axis showed a strong whole data set (Fig. 6). A clear spatial and seasonal pattern was observed among the predominant species, with optimal growth conditions for Cylindrospermopsis raciborskii $(C y l)$ and Lyngbya versicolor (Lyn) between April and July-August at the 3 stations, and optimal conditions for Fragilaria sp. (Fra) between December and March.

\section{DISCUSSION}

Analysis of the phytoplankton community in Lake Guiers between March 2002 and March 2003 reveals some similarities and some differences with the situation observed prior to the construction of Diama Dam on the Senegal River in 1985. Dia \& Reynauld (1982) described the occurrence of many species of diatoms 

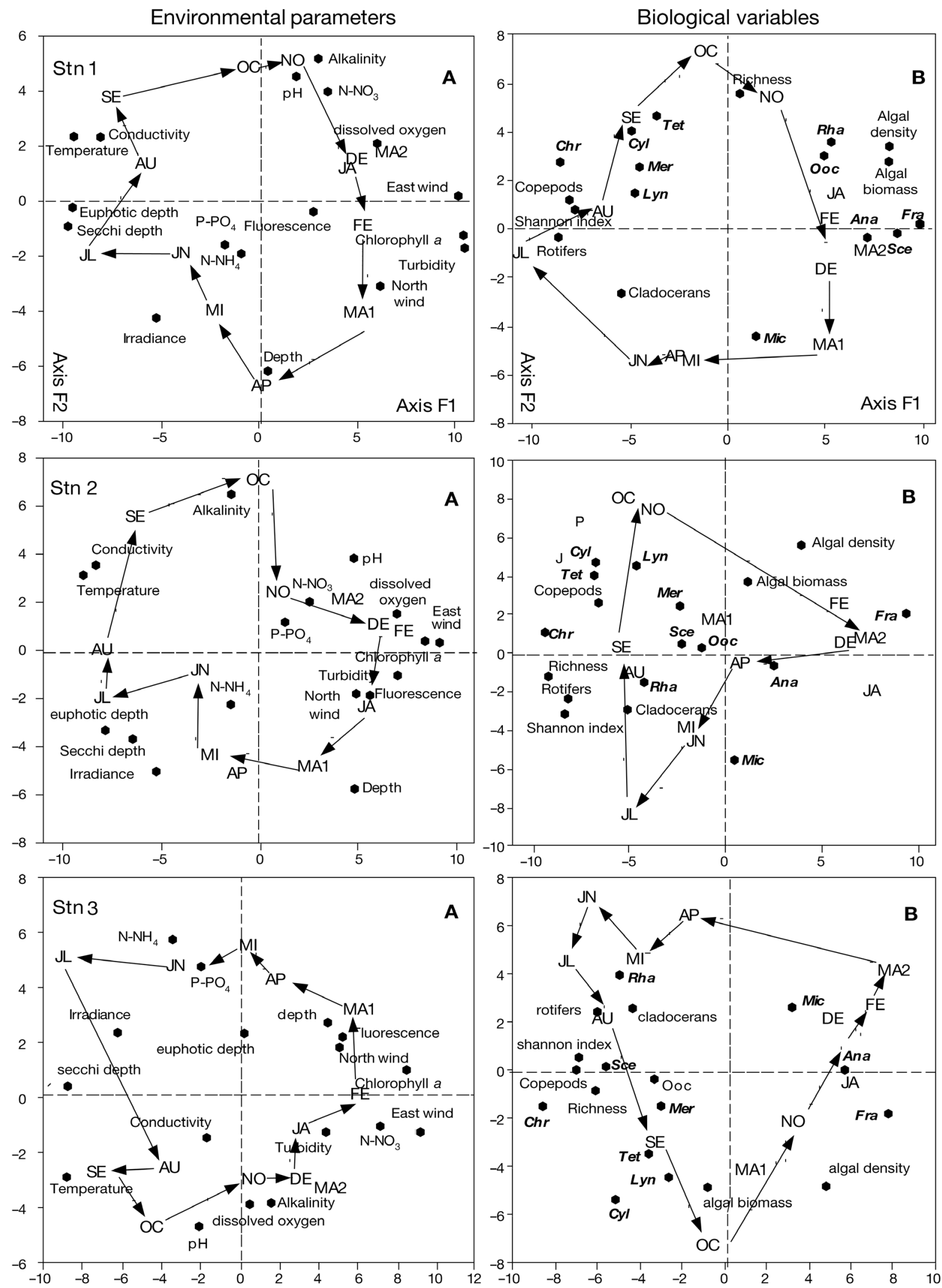

Fig. 6. Co-inertia analysis (CIA). Position of (A) environmental parameters and (B) biological variables on the F1 $\times$ F2 co-inertia planes. MA1: March 2002; AP: April; MI: May; JN: June; JL: July; AU: August; SE: September; OC: October; NO: November; DE: December; JA: January; FE: February; MA2: March 2003. See Table 2b for abbreviations of algal species 
and only a few species of cyanobacteria in Lake Guiers. The dam stabilised the water level in the lake and prevented seawater flowing up the Upper Senegal River valley. The subsequent hydrodynamic and hydrologic changes have induced marked modifications in the abiotic and biotic components of the ecosystem (Cogels et al. 2001): (1) a decrease in conductivity from 500 (North zone) to $4000 \mu \mathrm{S} \mathrm{cm}^{-1}$ (South zone) before the dam construction to a mean of $181 \mu \mathrm{S}$ $\mathrm{cm}^{-1}$ during our survey, and (2) an increase in chl a concentrations from an average of $25 \mu \mathrm{g} \mathrm{l}^{-1}$ before the dam (Dia \& Reynauld 1982) to $49 \mu \mathrm{g} \mathrm{l}^{-1}$ during our survey, with a peak of $70 \mu \mathrm{g} \mathrm{l}^{-1}$ in March 2003. Compared with the situation described before construction of Diama Dam in 1985, the phytoplankton assemblage in 2002-03 was quite different, revealed by (1) a severe diminution of species of Bacillariophyceae, (2) a different taxonomic composition, in particular for cyanobacteria, and (3) the emergence and growth of the potentially toxic cyanobacterium Cylindrospermopsis raciborskii, as described by a recent study (Berger et al. 2006). These modifications confirm increasing eutrophication of Lake Guiers, owing to several factors such as expanding agriculture (particularly irrigation) and other pressures associated with a rapidly increasing population (Varis \& Fraboulet-Jussila 2002). These observations corroborate the conclusions of studies of several Brazilian reservoirs (Bouvy et al. 2000, Huszar et al. 2000): that phytoplankton assemblages appear more suitable for defining the trophic state of lakes in tropical regions than the Organisation for Economic Cooperation and Development criteria (OECD 1982).

The high degree of association between the environmental and biological systems obtained from the CIA enabled us to make ecological interpretations of the predominant algal species in Lake Guiers. Clear links exist between the development of Cylindrospermopsis raciborskii (Nostocales) and Lyngbya versicolor (Oscillatoriales) and the environment in the lake, suggesting that the 2 species have several ecological affinities, inducing possible competition between them. The absence of relationships between abundances of these 2 cyanobacteria and dissolved nutrient levels is notable, as cyanobacteria are commonly encountered in nutrient-rich shallow reservoirs (Pearl 1988). However, C. raciborskii develops rapidly when nutrient concentrations are at their lowest levels, because this species takes advantage of its ability to assimilate ammonium and phosphate at low nutrient concentrations (Présing et al. 1996). It is clear that its capacity to fix atmospheric nitrogen and the presence of terminal heterocytes is also a determining factor for its proliferation in various aquatic systems (Padisák 1997). In Lake Guiers, $85 \%$ of trichomes had heterocytes, which enabled them to develop in low levels of DIN
(M. Bouvy unpubl. data). We can speculate that this high diazotrophic activity, which is very costly in terms of energy, was certainly one of the reasons for the absence of a C. raciborskii bloom in Lake Guiers. In comparison, Bouvy et al. (1999) reported a C. raciborskii bloom in Ingazeira Reservoir in northeast Brazil with a mean proportion of $12 \%$ of heterocytes reflecting higher nutrient concentrations (peaks of $200 \mu \mathrm{g}$ $\mathrm{NH}_{4}-\mathrm{N} \mathrm{l}^{-1}$ and $544 \mu \mathrm{g} \mathrm{PO}_{4}-\mathrm{P} \mathrm{l}^{-1}$ ) than reported in this study. Moreover, C. raciborskii distribution is considered as cosmopolitan (Padisák 1997) as the species is tolerant of low light intensities, accounting for its presence in turbid ecosystems in temperate as well as in tropical zones such as northeast Brazil (Bouvy et al. 1999).

The development of Cylindrospermopsis raciborskii between June and October in Lake Guiers was associated with the establishment of favourable physical and chemical conditions. The lake has a north-south orientation (see Fig. 1), so the predominance of NNW maritime trade winds from June to October resulted in a reduced fetch length and a modification of the general hydrodynamics in the lake. Vertical movements were less strong, reducing sediment resuspension and stabilising the water column. This period also coincided with high temperatures (close to $29^{\circ} \mathrm{C}$; Fig. 2), and these conditions were favourable for $C$. raciborskii growth in the lake, as previously reported by Berger et al. (2006). Padisák (1997) reported a lower temperature limit for the growth of this species $\left(22^{\circ} \mathrm{C}\right)$, whereas Mischke (2003) reported seasonal growth of $C$. raciborskii in German waters beginning at water temperatures above $17^{\circ} \mathrm{C}$. Havens et al. (1998) proposed that light, water column stability and temperature all have a direct impact on the phytoplankton community. They suggested that in Lake Okeechobee, Florida, USA, the driving force for phytoplankton succession was underwater irradiance, which is determined ultimately by wind speed and direction, insolation and thermal stability of the water column. Previous studies (Havens et al. 1996) demonstrated that Lyngbya spp., present in Lake Okeechobee, is a low light-adapted genus, as confirmed by the local adaptation of $L$. versicolor in Lake Guiers.

With the return of predominant continental NNE trade winds, which increased water mixing and turbulence, there was a clear change in the phytoplankton community from October to March, with the diatom species Fragilaria sp. becoming predominant. With changes in weather, the Senegal River floods between August and October, which increases nutrient concentrations and allows nutrient-limited species like Fragilaria sp. to grow faster, as demonstrated by Butterwick et al. (2005). Silt in flood water is loaded with nutrients and silicates (Krachler et al. 2005). According to 
Chisholm (1992), diatoms are good competitors under high silicate and low light conditions. High abundances of Fragilaria sp. coincided with the lowest temperatures, low light intensities and high turbidity owing to mixing of the water column with change of wind direction (CIA data, Fig. 6). These observations confirmed those of Reynolds (1984), revealing a predominance of diatoms, even in the wet season, when there is flushing and no stratification. A secondary cyanobacterium, Anabaena miniata (Nostocales), was often associated with the presence of Fragilaria sp. These 2 species thus did not have any ecological affinity with the 2 predominant cyanobacteria, which had a different dependency on wind direction and associated water column stability.

The colonial cyanobacterium Microcystis aeruginosa was present from March to May, characterised by conditions transitory between the 2 periods described above, thus exploiting the turbulence and homogenization of the water column to grow quickly. This species has gas vacuoles, giving it an excellent capacity for vertical migration (Reynolds 1988). Other cyanobacteria, such as the 3 Chroococcus species, did not have any affinity with the other groups, and were only observed when biovolumes and densities of total phytoplankton community were low. This result corroborates the observations by Padisák et al. (2003), who concluded that these species can predominate only if phytoplankton biovolume is low and the water column very stable. These conditions were observed in Lake Guiers between July and September. Finally, other secondary species such as several Chlorophyceae species showed strong environmental affinities with the predominant cyanobacteria Cylindrospermopsis raciborskii, and could co-exist with them. Paradoxically, between July and October, the dominance of $C$. raciborskii was not associated with a decrease in diversity (Shannon-Wiener's diversity index: 1.81 to 2.11 bits cell $^{-1}$ ), contrary to other studies that show its predominance (before an eventual bloom) to cause a drastic decrease in phytoplankton biodiversity (e.g. Bouvy et al. 2000, Dokulil \& Teubner 2000). Experiments have demonstrated that $C$. raciborskii cultures grow better in the water of Lake Guiers when a cortege of other phytoplankton species is present than in water without other phytoplankton (data not shown). It seems that there is commensalism between C. raciborskii and other algal species in Lake Guiers. It is also important to note that C. raciborskii clones isolated from Lake Guiers were not toxic (Berger et al. 2006).

Although the growth of algal species depends on local physiological adaptation, the algal community is evidently controlled by top-down factors such as grazing pressure exerted by zooplankton predators. Cylin- drospermopsis raciborskii was not subjected to high grazing pressure in Lake Guiers as a result of the rarity of potential zooplankton grazers (Kâ et al. 2006). The calanoid copepod Pseudodiaptomus hessei, which has been demonstrated experimentally to graze on C. raciborskii trichomes (Kâ et al. 2005), is present in various aquatic systems in Senegal but has disappeared from the central zone of Lake Guiers since hydrology was modified by the construction of Diama Dam in 1985. Kâ et al. (2006) and Bouvy et al. (2000) demonstrated in Lake Guiers and in the most eutrophic reservoirs in northeast Brazil, respectively, that rotifers predominate over copepods and large cladocerans, which are not effective at grazing filamentous cyanobacteria. Although grazing pressure by total zooplankton of Lake Guiers studied experimentally was not significant for C. raciborskii development, grazing pressure was significant for the diatom Fragilaria sp. in MayJune (N. Ba unpubl. data). In our survey, low Fragilaria sp. densities coincided with high zooplankton abundances (Fig. 6). As claimed by Lazzaro et al. (2003), eutrophic tropical systems are often characterised by opportunist piscivores and planktivores; predominant rotifers are considered to be inefficient grazers, and the presence of predominant inedible cyanobacteria in the phytoplankton leads to a tropical ecosystem where the phytoplankton population is regulated by fish, somewhat different from classic temperate ecosystems with trophic cascade regulation.

Finally, the phytoplankton community in Lake Guiers exhibited a clear succession of species groups: Fragilaria sp.-Anabaena miniata (November to March) $\rightarrow$ Microcystis aeruginosa (March to May) $\rightarrow$ Cylindrospermopsis raciborskii-Lyngbya versicolor (June to November). It should be noted that all these species are filamentous or colonial species, not easily edible by zooplankton predators (Bouvy et al. 2001, Lazzaro et al. 2003). The general outline of seasonal variations of the phytoplankton community observed in this tropical lake (Fig. 7) with interactions between flood, stability of the water column, temperature and occurrence of predominant species seems to occur frequently in shallow aquatic systems in tropical and subtropical regions. Havens et al. (1998) suggested that seasonal variations of cyanobacteria species composition (Nostocales/Oscillatoriales) were caused by light availability in the shallow Lake Okeechobee (Florida, USA), whereas Bouvy et al. (2003) suggested that the succession C. raciborskii-Raphidiopsis cf. mediterranea/Chlorococcales was caused by precipitation events and water column mixing processes in a northeast Brazilian reservoir. Conversely, in temperate systems (North German waters), Teubner (2000) suggested that the succession between cyanobacteria and diatoms was related to nutrients, in particular to seasonal variations of the N/P ratio. 


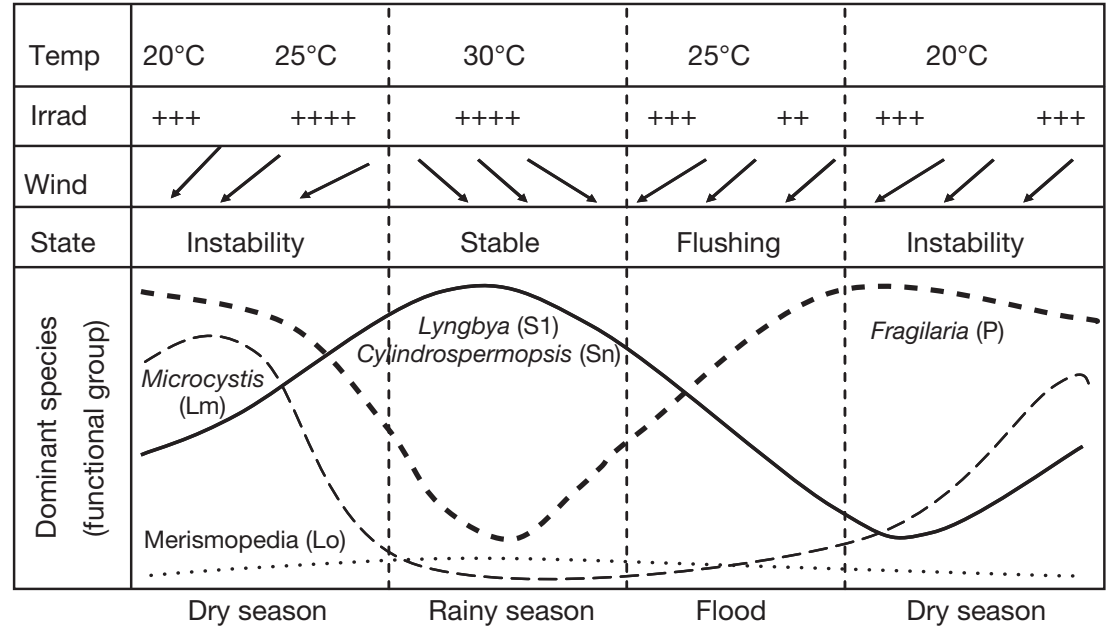

Fig. 7. Scheme of variations in abundance of cyanobacteria (Cylindrospermopsis raciborskii, Lyngbya versicolor, Microcystis aeruginosa and Merismopedia sp.) and diatoms (Fragilaria sp.) in relation to variation in temperature (Temp), solar irradiance (Irrad), wind direction (Wind), and stability of the water column (State) during the 3 periods identified (dry season, rainy season, flood) in Lake Guiers. Functional groups from scheme described by Reynolds et al. (2002) are noted for each dominant species (see Table 3)
It is clear that phytoplankton assemblages are influenced by environmental factors and, in the context of climatic equilibrium described by Reynolds et al. (1993), a set of combined factors can act jointly as a complex that selects seasonal groups of species sharing similar ecological requirements. Reynolds et al. (2002) therefore considered that a functional approach, based on the morphological-ecological properties of species, could be used as a quantitative method to describe phytoplankton community structure and changes. However, it is difficult to compare tropical algal assemblages with those described in temperate zones (Reynolds et al. 2002), and the present study may provide some support for functional groups in tropical ecosystems. Among the 31 functional groups identified by Reynolds et al. (2002) 11 predominant functional groups were identified during our study of the dynamics of the phytoplankton community in Lake Guiers in 2002-03 (Table 3): 7 groups represented the cyanobacteria community (Sn, H1, S1, X2, Lm, K and Lo), 1 group represented the Bacillariophyceae (P) and 3 groups represented the Chlorophyceae (X1, F and J).

Table 3. Annual mean and CV $(n=13)$ of density for total phytoplankton and 17 dominant algal species in Lake Guiers ( $>5 \%$ of relative abundance). For each species, functional group was identified and their habitats reported according to Reynolds et al. (2002) and Padisák et al. (2003)

\begin{tabular}{|lcccl|}
\hline & \multicolumn{2}{c}{$\begin{array}{c}\text { Density } \\
\text { Mean (cells l-1) }\end{array}$} & $\begin{array}{c}\text { Functional } \\
\text { group }\end{array}$ & Habitat/tolerance \\
\hline Total phytoplankton & $5.19 \times 10^{7}$ & 39.9 & & \\
Dominant species & & & & \\
Fragilaria sp. & $2.36 \times 10^{7}$ & 38.4 & $\mathrm{P}$ & Eutrophic layers/mild light, stratification \\
Cylindrospermopsis raciborskii & $9.52 \times 10^{6}$ & 28.6 & $\mathrm{Sn}$ & Warm stable layers/light, nitrogen deficient \\
Lyngbya versicolor & $7.33 \times 10^{6}$ & 27.3 & $\mathrm{~S} 1$ & Turbid stable layers/highly light deficient \\
Merismopedia glauca & $1.63 \times 10^{6}$ & 75.8 & Lo & Warm superficial layers/low nutrients \\
Merismopedia tenuissima & $6.27 \times 10^{5}$ & 54.6 & & \\
Merismopedia warmingiana & $3.51 \times 10^{5}$ & 85.6 & & \\
Anabaena miniata & $3.62 \times 10^{5}$ & 70.7 & $\mathrm{H} 1$ & Warm stable layers/light, nitrogen deficient \\
Chroococcus globosus & $3.20 \times 10^{5}$ & 145.6 & $\mathrm{X} 2$ & Clear mixed waters/stratification \\
Chroococcus limneticus & $6.64 \times 10^{5}$ & 77.9 & & \\
Chroococcus turgidus & $2.25 \times 10^{5}$ & 72.2 & & \\
Microcystis aeruginosa & $2.33 \times 10^{5}$ & 42.2 & Lm & Stable layers, eutrophic layer/very low carbon \\
Monoraphidium circinalis & $3.42 \times 10^{5}$ & 62.3 & $\mathrm{X} 1$ & Shallow mixed waters/stratification \\
Tetraedron caudatum & $4.23 \times 10^{5}$ & 35.0 & & \\
Tetraedron muticum & $2.68 \times 10^{5}$ & 35.2 & & \\
Rhabdoderma lineare & $7.98 \times 10^{5}$ & 104.0 & $\mathrm{~K}$ & Shallow turbid waters/high nutrients \\
Oocystis lacustrus & $2.12 \times 10^{5}$ & 45.3 & $\mathrm{~F}$ & Clear superficial layers/low nutrients, high turbidity \\
Scenedesmus magnus & $1.32 \times 10^{5}$ & 65.1 & $\mathrm{~J}$ & Shallow eutrophic layers/flushing \\
\hline
\end{tabular}


Group Sn, defined recently by Padisák \& Reynolds (1998), represented the heterocyclic Cylindrospermopsis raciborskii, often associated with nutrient-poor systems (especially in nitrogen) with high sensitivity to flushing and destratification. Padisak et al. (2003) concluded that Group Sn cannot join other non-cyanobacteria groups except $\mathrm{H} 1$ and S1, and our results corroborated this by demonstrating maximum growth of $C$. raciborskii (Sn) during the same period as that of Lyngbya versicolor (S1). These 2 groups have several ecological affinities, inducing competition between them. However, Group X1, usually present in rich shallow habitats and with great tolerance to stratification, was represented in this study by several chlorophyceae such as Monoraphidium circinalis and Tetraedron spp. This group showed strong environmental affinities and could co-exist with $C$. raciborskii. The joint presence of chlorophyceae and a predominant cyanobacteria such as C. raciborskii is noteworthy. The commensalism mentioned above would be an important target of future experimental research of these species.

In contrast to the conclusions of Huszar et al. (2000) and Romo \& Villena (2005), Chroococcus species (colonial cyanobacteria) were included in the first group X2 described by Reynolds et al. (2002), not in Group X1. Group X2, generally associated with a great sensitivity to mixing in meso-eutrophic shallow systems, was represented by the 3 Chroococcus species in Lake Guiers and had no affinity with other groups. These species were only observed when there was low biovolume and abundance of the total phytoplankton community, and our results highlight the isolation of these cyanobacteria by specific inclusion in Group X2. Group Lo refers to the association between 2 colonial species Peridinium-Woronichinia in stratified mesotrophic lakes (Reynolds et al. 2002). However, the 3 species of Merismopedia (colonial form) identified in this study could be placed in Group Lo, which is characterised by a tolerance to very low nutrient levels. Group P includes diatoms that require a continuous mixing (Reynolds et al. 2002). In our study, this group was represented by Fragilaria sp. and was almost always present and predominant during 6 months of the year.

It is clear that the functional groups described by Reynolds et al. (2002) and the species assemblages composing these groups must depend on the type of system subjected to various anthropogenic pressures under various climatic situations. The case of cyanobacteria is an interesting illustration of this. In the literature, cyanobacteria are frequently associated with eutrophic conditions in nutrient-rich systems (Reynolds 1984, Havens et al. 1998, Huszar et al. 2000). However Romo \& Villena (2005) demonstrated experimentally that cyanobacteria predominated over a wide range of nutrient levels. In Lake Guiers, nutrient con- centrations during the survey were low, with phosphate values always less than $10 \mu \mathrm{g} \mathrm{PO}_{4}-\mathrm{Pl}^{-1}$ and maximum ammonia values of $56 \mu \mathrm{g} \mathrm{NH}_{4}-\mathrm{N} \mathrm{l}^{-1}$ during the flood period. In spite of these low nutrient values, the cyanobacteria community exhibited high abundances and biovolumes (in particular Cylindrospermopsis raciborskii, which had an average abundance of $5.2 \times$ $10^{7}$ cells $\mathrm{l}^{-1}$ and biovolumes ranging between 11 and $98 \mathrm{~mm}^{3} \mathrm{l}^{-1}$ ), comparable to those observed in other tropical ecosystems (Havens et al. 1998, Bouvy et al. 1999, Lung'ayia et al. 2000). A small increase in the flushing rate (e.g. river flooding), such as occurs in Lake Guiers, may lead to the disappearance of cyanobacteria (Scheffer 1998). Group J, represented by Scenedesmus magnus, and Group $\mathrm{K}$, represented by Rhabdoderma lineare, are representative of shallow, turbid and nutrient-rich lakes (Padisák et al. 2003). These groups have a strong affinity with the environmental conditions present in Lake Guiers yearround, despite the very low nutrient levels observed. This study clearly demonstrates that the impact of nutrients on the development of predominant species (e.g. cyanobacteria) seems less significant than that of physical factors such as temperature, irradiance and water column stability, as shown by the CIA at the 3 stations.

In conclusion, regarding the environmental complex that characterises Lake Guiers, there is a clear succession of predominant species groups within the phytoplankton community of the lake: Fragilaria sp.-Anabeana miniata (November to March) following the flood of the Senegal River, during a period of low temperature and irradiance with NNE winds that mix the water column $\rightarrow$ Microcystis aeruginosa (March to May) $\rightarrow$ Cylindrospermopsis raciborskii-Lyngbya versicolor (June to November) during a period of high temperature and irradiance with predominant NNW winds and water column stability (Fig. 7). It is apparent that when the number of predominant species is small, and when their predominance persists throughout the year as observed in our study, phytoplankton dynamics might be more usefully characterised at the individual species level than by functional group (Kruk et al. 2002). However, application of the functional scheme for phytoplankton (Reynolds et al. 2002) to the algal community of Lake Guiers reveals valuable information on the algal strategies that characterise phytoplankton ecology in a shallow tropical lake, and confirms the local adaptations of some ubiquitous species. Some differences in responses of individual species were observed within functional groups, essentially concerning the secondary species groups such as X1 and X2. Finally, the driving forces that account for phytoplankton succession in Lake Guiers are mainly physical factors, and it seems that nutrient levels must 
be considered as secondary criteria in shallow tropical aquatic systems when defining functional groups using the scheme described by Reynolds et al. (2002) for temperate systems.

Acknowledgements. This study was a component of research dedicated to Lake Guiers (Senegal) and supported by the IRD Research Unit 'FLAG' 098 ('Key factors and consequences of algal blooms in shallow waters systems'). This study forms part of N.B.'s thesis under the supervision of M.B. We are grateful to 3 reviewers for their constructive criticisms and comments.

\section{LITERATURE CITED}

Albergel J, Bader JC, Lamagat JP, Seguis L (1993) Crues et sécheresses sur un grand fleuve tropical de l'Ouest africain: application à la gestion de la crue du fleuve Sénégal. Sécheresse 4:143-152

Berger C, Ba N, Gugger M, Bouvy M, Rusconi F, Couté A, Troussellier M, Bernard C (2006) Seasonal dynamics and toxicity of Cylindrospermopsis raciborskii in Lake Guiers (Senegal, West Africa). FEMS Microbiol Ecol 57:355-366

Bouvy M, Molica R, Oliveira S, Marinho M, Beker B (1999) Dynamics of a toxic cyanobacterial bloom (Cylindrospermopsis raciborskii) in a shallow reservoir in the semi-arid region of northeast Brazil. Aquat Microb Ecol 20:285-297

Bouvy M, Falcão D, Marinho M, Pagano P, Moura A (2000) Occurrence of Cylindrospermopsis (Cyanobacteria) in 39 Brazilian tropical reservoirs during the 1998 drought. Aquat Microb Ecol 23:13-27

Bouvy M, Pagano M, Troussellier M (2001) Effects of a cyanobacterial bloom (Cylindrospermopsis raciborskii) on bacteria and zooplankton communities in Ingazeira reservoir (northeast Brazil). Aquat Microb Ecol 25:215-227

Bouvy M, Nascimento SM, Molica RJR, Ferreira A, Huszar V, Azevedo S (2003) Limnological features in Tapacura reservoir (northeast Brazil) during a severe drought. Hydrobiologia 493:115-130

Butterwick C, Heaney SI, Talling JF (2005) Diversity in the influence of temperature on the growth rates of freshwater algae, and its ecological relevance. Freshw Biol 50: 291-300

Chisholm SW (1992) Phytoplankton size. In: Falkowski PG, Woodhead AD (eds) Primary production and biogeochemical cycles in the sea. Plenum Press, New York, p 213-237

Cogels FX, Gac JY (1993) Lake of Guiers (Senegal, West Africa). Int Lake Environ Comm (ILEC) Newsl 20:6-7

Cogels FX, Fraboulet-Jussila S, Varis O (2001) Multipurpose use and water quality challenges in Lac de Guiers (Senegal). Water Sci Tech 44:35-46

Compère $\mathrm{P}$ (1991) Contribution à l'étude des algues du Sénégal. Algues du lac de Guiers et du Bas Sénégal. Bull Jard Bot Nat Belg 61:171-267

Couté A, Rousselin (1975) Contribution à l'étude des algues d'eau douce du Moyen Niger (Mali). Bull Mus Nat Hist Paris Ser 3, 277 Bot 21:73-176

Descy JP, Hardy A, Sténuite S, Pirlot S and 5 others (2005) Phytoplankton pigments and community composition in Lake Tanganyika. Freshw Biol 50:668-684

Dia A, Reynaud PA (1982) Le phytoplancton du lac de Guiers: approche qualitative et quantitative. Cah ORSTOM Ser Biol 45:35-47

Dokulil MT, Teubner K (2000) Cyanobacterial dominance in lakes. Hydrobiologia 438:1-12
Dolédec S, Chessel D (1994) Co-inertia analysis: an alternative method for studying species-environment relationships. Freshw Biol 31:277-294

Gran G (1952) Determination of the equivalent point in potentiometric titrations. Part II. Analyst 77:661-671

Grönblad R, Prowse GA, Scott AM (1958) Sudanese desmids. Acta Bot Fenn 58:1-82

Havens KE, Aumen NG, James RT, Smith VH (1996) Rapid ecological changes in a large subtropical lake undergoing cultural eutrophication. Ambio 25:150-155

Havens KE, Phlips E, Cichra M, Li B (1998) Light availability as a possible regulator of cyanobacteria species composition in a shallow subtropical lake. Freshw Biol 39: $547-556$

Humpage AR, Rositano J, Baker PD, Nicolson BC, Steffesen DA, Bretag AH, Brown RK (1994) Paralytic shellfish poisons from the australian cyanobacterial blooms. Aust J Mar Freshw Res 45:761-771

Huszar VLM, Silva LHS, Marinho M, Domingos P, Sant'Anna CL (2000) Cyanoprokaryote assemblages in eight productive tropical Brazilian waters. Hydrobiologia 424:67-77

Huszar V, Kruk C, Caraco N (2003) Steady-state assemblages of phytoplankton in four temperate lakes (NE USA). Hydrobiologia 502:97-109

Kâ S, Pagano M, Bouvy M, Kouassi E, Champalbert G, Thiaw OT (2005) Feeding of Pseudodiaptomus hessei on filamentous cyanobacteria in tropical shallow reservoirs (Senegal). In: Souissi S, Daly Yahia MN (eds) IX Int Symp Copepods. Hammamet, 10-15 July 2005

Kâ S, Pagano M, Ba N, Bouvy M and 8 others (2006) Zooplankton distribution related to environmental factors and phytoplankton in a shallow tropical lake (Lake Guiers, Senegal, West Africa). Int Rev Hydrobiol 91:389-405

Komárek J, Anagnostidis K (1989) Modern approach to the classification system of cyanophytes. 4- Nostocales. Algol Stud 56:247-345

Krachler R, Jirsa F, Ayromlou (2005) Factors influencing the dissolved iron input by river water to the open ocean. Biogeosciences 2:311-315

Kruk C, Mazzeo N, Lacerot G, Reynolds CS (2002) Classification schemes for phytoplankton: a local validation of a functional approach to the analysis of species temporal replacement. J Plankton Res 24:901-912

Lauterborn R (1915) Die sapropelische lebewelt. (Ein Beitrag zur biologie des Faulschlammes. Natürlicher Gewässer). Verh Nathist Med Ver 13:317-323

Lazzaro X, Bouvy M, Filho RR, De Oliveira V, De Sales L, De Vasconcelos A, Da Mata M (2003) Do fish regulate phytoplankton in shallow eutrophic Northeast Brazilian reservoirs? Freshw Biol 48:649-668

Leonard JA, Paerl HW (2005) Zooplankton community structure, micro-zooplankton grazing impact, and seston energy content in the St. Johns river system, Florida as influenced by the toxic cyanobacterium Cylindrospermopsis raciborskii. Hydrobiologia 537:89-97

Lung'ayia HBO, M'Harzi A, Tackx M, Gichuki J, Symoens JJ (2000) Phytoplankton community structure and environment in the Kenyan waters of Lake Victoria. Freshw Biol 43:529-543

Mischke U (2003) Cyanobacterial associations in shallow polytrophic lakes: influence of environmental factors. Acta Oecol 24:11-23

OECD (Organisation for Economic Cooperation and Development) (1982) Eutrophication waters. Monitoring, assessment and control. OECD, Paris

Padisák J (1997) Cylindrospermopsis raciborskii (Woloszynska) Seenayya et Subba Raju, an expanding, highly adap- 
tive cyanobacterium: worldwide distribution and review of its ecology. Arch Hydrobiol Suppl 4:563-593

Padisák J, Reynolds CS (1998) Selection of phytoplankton associations in Lake Balaton, Hungary, in response to eutrophication and restoration measures, with special reference to cyanoprokaryotes. Hydrobiologia 384:41-53

Padisák J, Borics G, Fehér G, Grigorsky I, Oldal I, Schmidt A, Zamboné-Doma Z (2003) Dominant species, functional assemblages and frequency of equilibrium phases in late summer phytoplankton assemblages in Hungarian small shallow lakes. Hydrobiologia 502:157-168

Paerl HW (1988) Nuisance phytoplanktonic blooms in coastal, estuarine and inland waters. Limnol Oceanogr 33:823-847

Présing M, Herodek S, Vörös L, Kóbor I (1996) Nitrogen fixation, ammonium and nitrate uptake during a bloom of Cylindrospermopsis raciborskii in Lake Balaton. Arch Hydrobiol 136:553-562

Reynolds CS (1984) The ecology of freshwater phytoplankton. Cambridge University Press, Cambridge

Reynolds CS (1988) Functional morphology and the adaptive strategies of freshwater phytoplankton. In: Sandgren CD (ed) Growth and reproductive strategies of freshwater phytoplankton. Cambridge University Press, Cambridge, 261-315

Reynolds CS, Padisák J, Sommer U (1993) Intermediate disturbance in the ecology of phytoplankton and the maintenance of species diversity: a synthesis. Hydrobiologia 249: 183-188

Reynolds CS, Huszar V, Kruk C, Naselli-Flores L, Melo S (2002) Towards a functional classification of the freshwater phytoplankton. J Plankton Res 24:417-428

Romo S, Villena MJ (2005) Phytoplankton strategies and diversity under different nutrient levels and planktivorous fish densities in a shallow Mediterranean lake. J Plankton Res 27:1273-1286

Salmaso N (2003) Life strategies, dominance patterns and mechanisms promoting species coexistence in phyto-

Editorial responsibility: William Li,

Dartmouth, Nova Scotia, Canada plankton communities along complex environmental gradients. Hydrobiologia 502:13-36

Scheffer M (1998) Ecology of shallow lakes. Kluwer Academic, Dordrecht

Shannon CC, Weaver W (1963) The mathematical theory of communication. Illinois University Press, Urbana, IL

Skuja H (1956) Taxonomische und Biologische Studien über das Phytoplankton Schwedischer Binnengewässer. Nova Acta Reg Soc Sci Upsal IV 16:1-404

Smayda TJ (978) From phytoplankton to biomass. In: Sournia A (ed) Phytoplankton manual. Monographs on Oceanographic methodology 6. UNESCO, Paris, p 273-279

Sommer U (1989) Plankton ecology: succession of plankton communities. Springer-Verlag, Berlin

Strickland JDH, Parsons TT (1972) A practical handbook of seawater analysis. Bull Fish Res Board Can 167

Sun J, Liu D (2003) Geometric models for calculating cell biovolume and area for phytoplankton. J Plankton Res 25: $1331-1346$

Teubner K (2000) Synchronized changes of planktonic cyanobacterial and diatom assemblages in North German waters reduce seasonality to two principal periods. Arch Hydrobiol Spec Iss Adv Limnol 55:565-580

Thioulouse J, Chessel D, Dolédec S, Olivier JM (1997) ADE 4: a multivariate analysis and graphical display software. Stat Comp 7:75-83

Thornton KW, Kimmel BL, Payne FF (1990) Reservoir limnology: ecological perspectives. Wiley Interscience, New York

Utermöhl H (1958) Zur Vervollkommnung der quantitativen Phytoplankton Methodik. Mitt Int Ver Theor Angew Limnol 9:1-39

Varris O, Fraboulet-Jussila S (2002) Analysis of eutrophication level and critical loads of Lac de Guiers, Senegal. Verh Int Ver Theor Angew Limnol 28:462-466

Yentsch CS, Menzel DW (1963) A method for the determination of phytoplankton chlorophyll and phaeophytin by fluorescence. Deep-Sea Res 10:221-231

Submitted: June 8, 2006; Accepted: August 11, 2006

Proofs received from author(s): October 25, 2006 